\title{
Genotypic Effects on Morphological Characterization of Fruit Traits in Mulberry
}

Faruque Ahmed, Anwar Hossain, Nasir Uddin Ahmed, Md Jahangir Alam, and Md. Shoriful Islam

\section{ABSTRACT}

The research was conducted to evaluate the morphological variability in fruits traits among the mulberry genotypes grown in Mulberry Germplasm Bank of Bangladesh Sericulture Research and Training Institute (BSRTI), Rajshahi, during 2018-2020. The aim of the research was to find out the genotypes accessibility for varietal improvement. Total 50 mulberry genotypes were morphologically characterized on fruit traits through this research. The experimental design was Randomized Complete Block Design (RCBD) with three replications and the plantation system was high bush. Each plot consists of 20 plants and unit plot size was $4 \mathrm{~m} \times 5 \mathrm{~m}$. Fruit colour, fruit taste and seed colour was determined. Nine distinct fruit colours such as reddish-black $(\mathbf{2 3 . 3 3 \%})$, black-berry $(\mathbf{1 8 . 3 3 \%})$, cream $(\mathbf{1 0 \%})$, black $(8.33 \%)$, white-cream $(6.67 \%)$, pink $(6.67 \%)$, pinkish $(3.33 \%)$, orange $(3.33 \%)$ and radish $(1.67 \%)$ were observed among several germplasms. Remarkable variation was found in fruit taste such as sour sweet $(\mathbf{2 8 . 3 3 \%})$, sweet $(\mathbf{2 1 . 6 7 \%})$, light sweet $(\mathbf{5 \%})$, light-sour sweet $(\mathbf{5 \%})$ and deep sweet (5\%), respectively. Five colored of seed viz: light yellow, light brown, yellowish brown, dark brown and blackish brown were observed among the germplasm. Length of the fruit diverse from 0.73 (BSRM-8) to 5.58 (BSRM56 and widthfrom 0.52 (BSRM-8) to1.9 (BSRM-56),single fruit weight varied from 0.07 (BSRM-8) to 4.11 (BSRM-56), fruit weight per plant varied from 101.47 (BSRM-11) to 2250.43 (BSRM-56), seed setting (\%) varied from 8.13 (BSRM-29) to 94.24 (BSRM-16), sprouting (\%) varied from 36.67 (BSRM22) to 96.67 (BSRM-38), rooting (\%) varied from 13.89 (BSRM-22) to 98.33 (BSRM-10), achene number/fruit varied from 12.53 (BSRM-10) to118.10 (BSRM-56), seed number/fruit varied from 2.99 (BSRM-8) to 47.86 (BSRM56) and 100 seed weight varied from 0.019 (BSRM-35) to 0.166 (BSRM-56), respectively. Results showed that the black-berry, sweet tasted fruited mulberry (BSRM-56), cream colored, sweet tasted fruited mulberry (BSRM1) and white cream, sweet tasted fruited mulberry (BSRM-34) was promising on the basis of greatest fruit production potential to be appears for further commercial utilization. Generally, a wide range of variation was exhibited among the sampled and characterized genotypes.

Keywords: Genotype, Promising, Seed Setting, Sericulture, Silkworm.
Submitted : September 05,2021

Published: October 08,2021

ISSN: 2684-1827

DOI: $10.24018 /$ ejfood.2021.3.5.369

Faruque Ahmed*

Bangladesh Sericulture Research and Training Institute (BSRTI), Rajshahi, Bangladesh.

(e-mail: moistfaruk@gmail.com)

Anwar Hossain

Department of Agricultural Extension (DAE), Gafarrgaon, Mymensingh, Bangladesh.

(e-mail: diganta201484@gmail.com)

Nasir Uddin Ahmed

Wave Foundation, Bangladesh.

(e-mail: nasir8506@ gmail.com)

Md. Jahangir Alam

Development of cotton research and technology transfer project, Cotton Development Board, Bangladesh.

(e-mail: jahangircdb@gmail.com) Md. Shoriful Islam

Christian Commission for Development in Bangladesh, Bangladesh.

(e-mail: shorifu18147@gmail.com)

*Corresponding Author

\section{INTRODUCTION}

The mulberry (Morus spp.; Family- Moraceae) is an important Sericultural industry foliage plant for sole feed for silkworms and most of the research has been conducted on mulberry leaves. Because in sericulture sector mulberry fruit is considered of no use and a little study has focused on mulberry fruit. It is widely dispersed and can grow in a wide range of climatic, topographical, and soil conditions throughout the world by [1]. Mulberry is originated in the boundary area of the Indo-Chinese region and scattered in the lower slopes of the sub-Himalayan zone up to an elevation of $3300 \mathrm{~m}$ reported by [2]. In the world approach three main species, viz: white mulberry (Morus alba), red mulberry (Morus rubra), and the black mulberry (Morus nigra) are the commonly disseminated and used mulberries reported by [3]. These three major mulberry species originated from diverse areas of the world. However, in the Eastern United States red mulberry (the American mulberry) is native, white mulberry, bred for silkworm production and fruit cultivation, native to China and the black mulberry is native to Asia reported by [4]-[6].

Mulberry, an important commercial crop, is cultivated extensively for its foliage which is the sole food for domesticated silkworm, Bombyx mori including Bangladesh. Mulberry fruit contains various kinds of nutrient compounds viz: amino acids, minerals, and vitamins. Now, mulberry can also be utilized for catering of diversified requirements such as food, fodder, fuel, and fibre except only the solitary food of domesticated mulberry silkworm (Bombyx mori). The ripe mulberry fruits are decidedly cherished for their delicious taste, and which are also consumed either fresh or after extraction of juice. Due to contain of biologically active ingredients mulberry fruits might be associated with some potential pharmacological actions. Thus, mulberry fruits have a valuable impact on health benefits. Most of the mulberry- 
growing countries of the world due to delicious taste, pleasing colour, low calorie and high nutrient content of mulberry fruit it is usually eaten as fresh, dried, or processed into wine, fruit juice, and jam for [3],[7],[8]. Currently berries crops have gained enormous implication due to their value in the diet visa-vis human health as they are prosperous sources of antioxidant [9] which are vastly dependent on the genotypes [10]. Especially in European countries mulberry fruit has recognized as 'superfood' status due to the presence of bioactive compounds reported by [11]-[14].

In Bangladesh generally a number of mulberry cultivars are grown only as a solitary feed for mulberry silkworm rearing. In present situation mulberry cultivation is beginning popular as an edible food over the world but in Bangladesh it is a totally new scheme. However, in very recent the people of Bangladesh are being interested to growing mulberry as an edible food for its high nutrient content, tasty, content low calorie, pleasant colour, health benefits as well as financially viable benefits. Now mulberry grown practically more or less all over the country but the fruit production of these varieties or cultivars is comparatively low due to the lack of introducing of improved fruiting variety [15]. Characterization is the absolutely fundamental task to provide information for hybridization as well as breeding programs [16]. Knowledge of characterization and evaluation of the germplasm will help the further varietal improvement program. The reorganization of the variability and to improve the local germplasm and also easily as well as quickly evaluation of collected germplasm characterization is the obligatory task. Besides, a Plant breeder has relied over the years on phenotypic characterization for cultivation of a cultivar [17], [18]. The registration and protection of new cultivars morphological characterization is the official method reported by [19]. Different morphotypes of mulberry are existing in Bangladesh Plant Genectic Resources Centre (PGRC) of Bangladesh Sericulture Research and Training Institute (BSRTI) collected and conserved different types of mulberry germplasm from home and abroad. But the morphological characterization of mulberry germplasm on horticultural traits has not been conducted systematically. That's why, the present research was carried out to morphological characterize of mulberry germplasm to provide useful information on fruit traits for further breeding programs as well as to promote the use of these genetic resources.

\section{MATERIALS AND METHODS}

\section{A. Plant Material}

The Mulberry Germplasm Bank of the Bangladesh Sericulture Research and Training Institute (BSRTI), Rajshahi, Bangladesh, recently are being maintaining 84 genotypes including wild and developed species under field condition. Among them, 50 fruit-using mulberry genotypes were characterized on morphological-traits (Table I).

\section{B. Evaluation of Fruit Traits}

The experiment was conducted at the Mulberry Gemrplasm Bank of BSRTI, Rajshahi. Five plants were transplanted from each genotype. The normal cultural practices viz: recommended doses of manure and fertilizers such as $15 \mathrm{MT} / \mathrm{ha}$ cowdung, N300P150K100 kg/ha per year with two split doses were applied in the experimental field [20]. The other cultural practices like- digging cum weeding, irrigation, pruning and disease-pest control were followed as per needed. Mulberry fruit traits, including fruit colour, taste, seed colour, fruit length, fruit width, single fruit weight, fruit weight/plant, seed setting $\%$, sprouting $\%$, rooting $\%$, achene number/fruit, seed number/fruit and 100 seed weight, were evaluated during the fruit-growing season from five different plants for each genotype. Total thirteen (13) observations on qualitative (03) and quantitative (10) characters were recorded following the descriptor and acceptable to International Compendium Programme and International Board of Plant Genetic Resources (IBPGR) of [21] and [22].

TABLE I: LIST OF MULBERRY GERMPLASM CHARACTERIZED DURING 2018

\begin{tabular}{|c|c|c|c|}
\hline Sl. No. & $\begin{array}{c}\text { Germplasm/Genotypes } \\
\text { name }\end{array}$ & $\begin{array}{c}\text { Accession } \\
\text { number }\end{array}$ & Remarks \\
\hline 1. & White mulberry & BSRM-1 & Bangladesh local \\
\hline 2. & Black mulberry & BSRM-2 & Bangladesh local \\
\hline 3. & Bombay & BSRM-3 & Bangladesh local \\
\hline 4. & Bangla local & BSRM-4 & Bangladesh local \\
\hline 5. & BM-1 & BSRM-5 & Bangladesh develop \\
\hline 6. & Bangla local & BSRM-6 & Bangladesh local \\
\hline 7. & Bangla local & BSRM-7 & Bangladesh local \\
\hline 8. & Tellia & BSRM-8 & Bangladesh local \\
\hline 9. & Bangla local & BSRM-10 & Bangladesh local \\
\hline 10. & Bangla local & BSRM-11 & Bangladesh local \\
\hline 11. & Dudiya & BSRM-12 & Bangladesh local \\
\hline 12. & Sadabombay & BSRM-13 & Bangladesh local \\
\hline 13. & Lal bombay & BSRM-14 & Bangladesh local \\
\hline 14. & Kanva-2 & BSRM-15 & Indian developed \\
\hline 15. & BM-4 & BSRM-16 & Bangladesh develop \\
\hline 16. & BM-2 & BSRM-18 & Bangladesh develop \\
\hline 17. & BM-3 & BSRM-19 & Bangladesh develop \\
\hline 18. & S-54 & BSRM-20 & Indian develop \\
\hline 19. & Jink & BSRM-21 & China develop \\
\hline 20. & Lup-40 & BSRM-22 & China develop \\
\hline 21. & Indian local & BSRM-23 & Idian local \\
\hline 22. & Bangla develop & BSRM-25 & Bangladesh develop \\
\hline 23. & Bangla develop & BSRM-26 & Bangladesh develop \\
\hline 24. & Bangla develop & BSRM-27 & Bangladesh develop \\
\hline 25. & Morus laevigata & BSRM-28 & Indigenous wilt \\
\hline 26. & Bangla develop & BSRM-29 & Bangladesh develop \\
\hline 27. & Bangla develop & BSRM-30 & Bangladesh develop \\
\hline 28. & Bangla develop & BSRM-33 & Bangladesh develop \\
\hline 29. & BM-7 & BSRM-34 & Bangladesh develop \\
\hline 30. & Bangla develop & BSRM-35 & Bangladesh develop \\
\hline 31. & Bangla develop & BSRM-36 & Bangladesh develop \\
\hline 32. & Bangla develop & BSRM-37 & Bangladesh develop \\
\hline 33. & Bangla develop & BSRM-38 & Bangladesh develop \\
\hline 34. & S-30 & BSRM-40 & Indian develop \\
\hline 35. & S-36 & BSRM-42 & Indian develop \\
\hline 36. & BM-6 & BSRM-45 & Bangladesh develop \\
\hline 37. & MR-2 & BSRM-46 & Indian develop \\
\hline 38. & $\mathrm{R}-135$ & BSRM-47 & Indian develop \\
\hline 39. & Kosen & BSRM-48 & Japan develop \\
\hline 40. & Mijusawa & BSRM-49 & Japan develop \\
\hline 41. & Multicaules & BSRM-50 & Japan develop \\
\hline 42. & Bird-foot & BSRM-51 & Indian develop \\
\hline 43. & Bangla wilt & BSRM-53 & Bangladesh local \\
\hline 44. & China diploid & BSRM-54 & China develop \\
\hline 45. & China triploid & BSRM-55 & China develop \\
\hline 46. & BM-8 & BSRM-56 & Bangladesh develop \\
\hline 47. & BM-9 & BSRM-58 & Bangladesh develop \\
\hline 48. & OP-146 & BSRM-59 & Bangladesh develop \\
\hline 49. & $V-5$ & BSRM-60 & Indian develop \\
\hline 50. & China & BSRM-61 & China develop \\
\hline
\end{tabular}




\section{Descriptor and Descriptor States}

\section{1) Qualitative Descriptor}

Fruit colour (In the main flowering season data was recorded by selecting fully matured fruits in the longest shoot): In full ripen stage the colour of the fruits was recorded and graded on visual observation. Radish-black $=1$, Blackberry $=2$, Cream $=3$, Black $=4$, White-cream $=5$, Pink $=6$, Pinkish $=7$, Orange $=8$ and Radish $=9$.

Fruit taste (Recorded in the main flowering season by selecting fully matured fruits in the longest shoot): The fruit taste was recorded when the fruits were full ripen stage. Here,
Sour-sweet $=1$, Sweet $=2$, Light sweet $=3$, Light-sour sweet $=4$ and deep sweet $=5$.

Seed colour (Seed colour was recorded in the main flowering season by selecting fully matured fruits in the longest shoot. After harvesting of seeds from the ripened fruits the seed colour was recorded by observing under the stereo microscope): Here, Light yellow $=1$, Light brown $=2$, Yellowish brown $=3$, Dark brown $=4$ and Blackish brown $=$ 5.

\section{2) Quantitative Descriptors}

TABLE II: QUANTITATIVE DESCRIPTORS

\begin{tabular}{|c|c|c|c|}
\hline SI. No. & Descriptor & Growth stage and time for data recording & Method \\
\hline 1. & Fruit length $(\mathrm{cm})$ & $\begin{array}{l}\text { Recorded in the main flowering season by } \\
\text { selecting the fully matured fruits in the } \\
\text { longest shoot }\end{array}$ & $\begin{array}{l}\text { The data was recorded when the fruits were in full ripening stage. } \\
\text { The length of the full fruits including the peduncle. Total } \\
\text { randomly } 9 \text { fruits from three plants were considered collecting } 3 \\
\text { fruits from a plant. }\end{array}$ \\
\hline 2. & Fruit width $(\mathrm{cm})$ & $\begin{array}{l}\text { Recorded in the main flowering season by } \\
\text { selecting the fully matured fruits in the } \\
\text { longest shoot }\end{array}$ & $\begin{array}{l}\text { The data was recorded when the fruits were in full ripening stage. } \\
\text { The breath of the full fruits including the peduncle. Total } 9 \text { fruits } \\
\text { from three plants were considered collecting } 3 \text { fruits from a plant. }\end{array}$ \\
\hline 3. & Single fruit weight (g) & $\begin{array}{l}\text { Recorded in the main flowering season by } \\
\text { selecting the fully matured fruits in the } \\
\text { longest shoot }\end{array}$ & $\begin{array}{l}\text { The same fruits which were used for taking the data on length and } \\
\text { breadth that were used for taking the weight of fruits individually. }\end{array}$ \\
\hline 4. & Fruit weight per plant (g) & Recorded in the main flowering season & $\begin{array}{l}\text { The sum of the total fruit weight at different harvesting date was } \\
\text { divided by number of plants to get yield (average) per plant. }\end{array}$ \\
\hline 5. & Seed setting $(\%)$ & $\begin{array}{l}\text { Recorded in the main flowering season by } \\
\text { selecting the fully matured fruits in the } \\
\text { longest shoot }\end{array}$ & $\begin{array}{l}\text { The data was recorded when the fruits were in full ripening stage. } \\
\text { It was the ratio between total numbers of healthy seeds/fruit to the } \\
\text { total number of achenes/fruits. }\end{array}$ \\
\hline 6. & Sprouting $(\%)$ & $\begin{array}{l}\text { Recorded } 20 \text { days after plantation of } \\
\text { cutting in earthen pot. }\end{array}$ & $\begin{array}{l}\text { Percentage of sprouted cuttings out of total planted cuttings was } \\
\text { counted manually. }\end{array}$ \\
\hline 7. & Rooting (\%) & $\begin{array}{l}\text { Rooting percentage was recorded based } \\
\text { on the survival rate after } 90 \text { days of } \\
\text { plantation. }\end{array}$ & $\begin{array}{l}\text { Rooting percentage was recorded based on the survival rate after } \\
90 \text { days of plantation. }\end{array}$ \\
\hline 8. & Achene number/fruit & $\begin{array}{l}\text { Recorded in the main flowering season by } \\
\text { selecting the fully matured fruits in the } \\
\text { longest shoot }\end{array}$ & $\begin{array}{l}\text { Numbers of achenes/fruit were counted manually by separating } \\
\text { the achenes from the sorosis. }\end{array}$ \\
\hline 9. & Seed number/fruit & $\begin{array}{l}\text { Recorded in the main flowering season by } \\
\text { selecting the fully matured fruits in the } \\
\text { longest shoot }\end{array}$ & $\begin{array}{l}\text { Separated achenes were crashed together by the finger tip and } \\
\text { seeds were separated from the pulp by allowing standing in a tray } \\
\text { containing water. Then the derbies from the tray were washed out } \\
\text { and the number of seeds/fruit was counted manually. }\end{array}$ \\
\hline 10. & 100 seed weight $(\mathrm{g})$ & $\begin{array}{l}\text { Recorded in the main flowering season by } \\
\text { selecting the fully matured fruits in the } \\
\text { longest shoot }\end{array}$ & $\begin{array}{l}\text { Data was measured as average weight of } 100 \text { randomly selected } \\
\text { oven dry seeds. }\end{array}$ \\
\hline
\end{tabular}

\section{Statistical Analysis}

Experimental data on fruit traits were analyzed of range, mean, SD and mean coefficient of variation (CV\%) of quantitative characters were calculated using the analytic tools of Microsoft Excel software. Analysis of correlations between the fruits traits and associations among the genotypes by principal component analysis (PCA) was completed by applying the RStudio computer software.

\section{RESULTS AND DISCUSSION}

\section{A. Qualitative Characters}

Qualitative traits of fruits such as fruit colour, fruit test and seed colour exhibited distinct variations (Table II). The fruit colour showed the maximum variation. Nine categories of fruit colour such as reddish black (30\%), blackberry (22\%), cream $(12 \%)$, black $(10 \%)$, white cream $(8 \%)$, pink $(8 \%)$, pinkish $(4 \%)$, orange $(4 \%)$ and reddish $(2 \%)$ were observed among the germplasm at maturity stage after 90 days of pruning. The reddish black colour fruits were markedly and black-berry was medium. The cream coloured fruits were observed in germplasm BSRM-1, BSRM-5, BSRM-25, BSRM-30, BSRM-33 and BSRM-51 and the black coloured fruit was found in germplasm BSRM-4, BSRM-18, BSRM23, BSRM-27 and BSRM-58. These finding was lined with the previous finding of [8] who found the diverse colored fruits among the mulberry genotypes. They indentified three colour of mulberry fruits viz: black, white and red among the 93 genotypes with maximum colour was black. Similarly, they [23] determined the two colour of mulberry fruits among the 10 selected genotypes belonging to the 3 mulberry species (Morus alba, Morus rubra and Morus laevigata) viz: white colour and red colour but dominant was white colour. Likewise, fruit colour was varied greatly from white to black with diverse color shades upon ripening viz. white mulberries can produce white, lavender, or even black fruits depending, to certain extent, on the timing of harvest [24]. They also found that the over ripened white mulberry fruits turn into somewhat black due to delay of harvesting. Correspondingly, the coloring compounds tend to concentrate in the outer drupelets' cells in Morus alba, whereas in the fruits of Morus 
nigra and Morus rubra, these substances concentrate in all the cells of drupelets [4]. In our studied germplasm nine colored of fruit was determined may be due to the variability of number of species and genetic diversity among these species. Fruit taste exhibited as sour-sweet, sweet, lightsweet, light-sour sweet, deep-sweet and sour categories respectively. Out of 50 germplasm $36 \%$ fruits were soursweet, $30 \%$ sweet, $16 \%$ light sweet, $6 \%$ light sour sweet, $6 \%$ deep sweet and $6 \%$ sour respectively in taste. However, sour sweet fruit was markedly and sweet fruit moderately in our studied germplasm (Table III). The recorded sour-sweet germplasm were BSRM-4, BSRM-8, BSRM-14, BSRM-15, BSRM-18, BSRM-20, BSRM-23, BSRM-31, BSRM-34, BSRM-35, BSRM-36, BSRM-38, BSRM-41, BSRM-43, BSRM-45, BSRM-47 and BSRM-50 as well as fruits of BSRM-1, BSRM-9, BSRM-11, BSRM-16, BSRM-21, BSRM-24, BSRM-28, BSRM-29, BSRM-30, BSRM-37, BSRM-40, BSRM-42, BSRM-46, BSRM-48 and BSRM-49 germplasm were sweet in taste (Table III).
This finding was also similar with previous finding of [4] who reported that fruits of White mulberry are generally very sweet; red mulberry fruits are sweet and usually deep red or almost black. Whereas, black mulberry fruits are attractive, large, and juicy, with a good balance of sweetness and tartness that makes them the best-flavored fruits in mulberry. Among the studied germplasm total five categories of seed colour was observed such as light yellow (38\%), light brown (24\%), yellowish brown (18), dark brown (4\%) and blackish brown (16\%) respectively at fully ripen stage (Table III) may be due to the unpredictable genetic characters of studied germplasm species which was corresponding with the previous finding of [15]. He reported four colour of seed viz: dark brown, light yellow, blackish brown and yellowish brown respectively among the 45 mulberry genotypes might be due to the unpredictability of mulberry species. The qualitative descriptors for individual germplasm are presented (Table IV).

TABLE III: MORPHOLOGICAL VARIABILITY OF 50 MULBERRY GERMPLASMS BASED ON QUALITATIVE FRUIT TRAITS DURING 2018 -2020

\begin{tabular}{|c|c|c|c|c|c|}
\hline SI. No. & Descriptor & Descriptor state & No. of germplasm & $\%$ of germplasm & Germplasm (Serial number in table I) \\
\hline \multirow{9}{*}{1.} & \multirow{9}{*}{ Fruit colour } & 1.1 Reddish black & 15 & 30 & $\begin{array}{c}8,12,19,20,23,33,34,35,36,38,39 \\
43,44,45,50\end{array}$ \\
\hline & & 1.2 Black-berry & 11 & 22 & $2,4,6,9,10,11,14,15,18,31,46$ \\
\hline & & 1.3 Cream & 6 & 12 & $1,5,22,27,28,42$, \\
\hline & & 1.4 Black & 5 & 10 & $3,16,21,24,47$ \\
\hline & & 1.5 White-cream & 4 & 8 & $7,29,37,48$ \\
\hline & & 1.6 Pink & 4 & 8 & $17,30,32,40$ \\
\hline & & 1.7 Pinkish & 2 & 4 & 13,25 \\
\hline & & 1.8 Orange & 2 & 4 & 26,41 \\
\hline & & 1.9 Reddish & 1 & 2 & 49 \\
\hline \multirow{6}{*}{2.} & \multirow{6}{*}{ Fruit taste } & 2.1 Sour-sweet & 18 & 36 & $\begin{array}{c}4,8,12,14,15,18,20,23,31,34,35,36 \\
38,41,43,45,47,50\end{array}$ \\
\hline & & 2.2 Sweet & 15 & 30 & $\begin{array}{c}1,9,11,16,21,24,28,29,30,37,40,42 \\
46,48,49\end{array}$ \\
\hline & & 2.3 Light- sweet & 8 & 16 & $2,5,7,13,22,25,26,27$ \\
\hline & & 2.4 Light-sour sweet & 3 & 6 & $3,6,10$ \\
\hline & & 2.5 Deep sweet & 3 & 6 & $17,32,44$, \\
\hline & & 2.6 Sour & 3 & 6 & $19,33,39$ \\
\hline \multirow{5}{*}{3.} & \multirow{5}{*}{ Seed colour } & 3.1 Light yellow & 19 & 38 & $\begin{array}{c}1,4,8,12,13,20,21,23,24,27,31,32, \\
33,36,38,39,44,45,47\end{array}$ \\
\hline & & 3.2 Light brown & 12 & 24 & $3,5,6,7,11,14,15,28,29,40,43,49$ \\
\hline & & 3.3 Yellowish brown & 9 & 18 & $2,16,18,22,25,26,34,35,46$ \\
\hline & & 3.4 Dark brown & 2 & 4 & 9,50 \\
\hline & & 3.5 Blackish brown & 8 & 16 & $10,17,19,30,37,41,42,48$ \\
\hline
\end{tabular}

TABLE IV: LISTING OF QUALITATIVE DESCRIPTORS OF 50 MULBERRY GERMPLASM ON BASED OF

\begin{tabular}{ccccc}
\multicolumn{5}{c}{ FRUIT TRAITS } \\
\hline SI. No. & Acc. No. & Fruit colour & Fruit test & Seed colour \\
\hline 1. & BSRM-1 & Cream & Sweet & Light yellow \\
2. & BSRM-2 & Black- berry & Light sweet & Yellowish brown \\
3. & BSRM-3 & Black & Light sour- sweet & Light brown \\
4. & BSRM-4 & Black- berry & Sour- sweet & Light yellow \\
5. & BSRM-5 & Cream & Light sweet & Light brown \\
6. & BSRM-6 & Black- berry & Light sour- sweet & Light brown \\
7. & BSRM-7 & White cream & Light sweet & Light brown \\
8. & BSRM-8 & Reddish black & Sour- sweet & Light yellow \\
9. & BSRM-10 & Black-berry & Sweet & Dark brown \\
10. & BSRM-11 & Black-berry & Light sour sweet & Blackish brown \\
11. & BSRM-12 & Black-berry & Sweet & Light brown \\
12. & BSRM-13 & Reddish-black & Sour sweet & Light yellow \\
13. & BSRM-14 & Pinkish & Light sweet & Light yellow \\
14. & BSRM-15 & Black-berry & Sour- sweet & Light brown \\
15. & BSRM-16 & Black-berry & Sour sweet & Light brown \\
16. & BSRM-18 & Black & Sweet & Yellowish brown
\end{tabular}


TABLE IV: LISTING OF QUALITATIVE DESCRIPTORS OF 50 MULBERRY GERMPLASM ON BASED OF

\begin{tabular}{|c|c|c|c|c|}
\hline SI. No. & Acc. No. & Fruit colour & Fruit test & Seed colour \\
\hline 17. & BSRM-19 & Pink & Deep sweet & Blackish brown. \\
\hline 18. & BSRM-20 & Black-berry & Sour- sweet & Yellowish brown \\
\hline 19. & BSRM-21 & Reddish black & Sour & Blackish brown \\
\hline 20. & BSRM-22 & Reddish black & Sour- sweet & Light yellow \\
\hline 21. & BSRM-23 & Black & Sweet & Light yellow \\
\hline 22. & BSRM-25 & Cream & Light sweet & Yellowish brown \\
\hline 23. & BSRM-26 & Reddish black & Sour- sweet & Light yellow \\
\hline 24. & BSRM-27 & Black & Sweet & Light yellow \\
\hline 25. & BSRM-28 & Pinkish & Light sweet & Yellowish brown \\
\hline 26. & BSRM-29 & Orange & Light sweet & Yellowish brown \\
\hline 27. & BSRM-30 & Cream & Light sweet & Light yellow \\
\hline 28. & BSRM-33 & Cream & Sweet & Light brown \\
\hline 29. & BSRM-34 & White cream & Sweet & Light brown \\
\hline 30. & BSRM-35 & Pink & Sweet & Blakish brown \\
\hline 31. & BSRM-36 & Black-berry & Sour- sweet & Light yellow \\
\hline 32. & BSRM-37 & Pink & Deep sweet & Light yellow \\
\hline 33. & BSRM-38 & Reddish black & Sour & Light yellow \\
\hline 34. & BSRM-40 & Reddish black & Sour- sweet & Yellowish brown \\
\hline 35. & BSRM-42 & Reddish black & Sour- sweet & Yellowish brown \\
\hline 36. & BSRM-45 & Reddish black & Sour- sweet & Light yellow \\
\hline 37. & BSRM-46 & White cream & Sweet & Blackish brown. \\
\hline 38. & BSRM-47 & Reddish black & Sour- sweet & Light yellow \\
\hline 39. & BSRM-48 & Reddish black & Sour & Light yellow \\
\hline 40. & BSRM-49 & Pink & Sweet & Light brown \\
\hline 41. & BSRM-50 & Orange & Sour-sweet & Blackish brown. \\
\hline 42. & BSRM-51 & Cream & Sweet & Blackish brown. \\
\hline 43. & BSRM-53 & Reddish black & Sour sweet & Light brown \\
\hline 44. & BSRM-54 & Reddish Black & Deep sweet & Light yellow \\
\hline 45. & BSRM-55 & Reddish black & Sour sweet & Light yellow \\
\hline 46. & BSRM-56 & Black-berry & Sweet & Yellowish brown \\
\hline 47. & BSRM-58 & Black & Sour sweet & Light yellow \\
\hline 48. & BSRM-59 & White cream & Sweet & Blackish brown. \\
\hline 49. & BSRM-60 & Reddish & Sweet & Light brown \\
\hline 50. & BSRM-61 & Reddish black & Sour sweet & Dark brown \\
\hline
\end{tabular}

\section{A. Quantitative Characters}

The first approach towards the assessment of genetic diversity of any plant species is morphological investigation reported by [25]. The present study showed the morphological variations among the 50 mulberry genotypes belonging to 08 mulberry species (Morus alba, Morus indica, Morus bombysis, Morus sinensis, Morus rubra, Morus laevigata and Morus nigra). Range, men, standard deviation and $\mathrm{CV} \%$ of the quantitative data of mulberry is presented (Table V).

TABLE V: DESCRIPTORS STATISTICS OF MULBERRY GERMPLASM BASED ON QUANTITATIVE TRAITS OF FRUITS DURING 2018-2020

\begin{tabular}{|c|c|c|c|c|c|c|}
\hline \multirow{2}{*}{$\begin{array}{l}\text { SI. } \\
\text { No. }\end{array}$} & \multirow{2}{*}{ Characters } & \multicolumn{2}{|c|}{ Range } & \multirow{2}{*}{ Mean } & \multirow{2}{*}{ SD } & \multirow{2}{*}{$\begin{array}{l}\text { CV } \\
(\%)\end{array}$} \\
\hline & & Max. & Min. & & & \\
\hline 1. & Fruit length $(\mathrm{cm})$ & 5.58 & 0.73 & 3.155 & 0.78 & 24.72 \\
\hline 2. & Fruit width $(\mathrm{cm})$ & 1.9 & 0.52 & 1.21 & 0.34 & 28.10 \\
\hline 3. & Single fruit weight $(\mathrm{g})$ & 4.11 & 0.07 & 2.09 & 0.82 & 39.23 \\
\hline 4. & Fruit weight/plant (g) & 2250.43 & 101.47 & 1175.95 & 448.75 & 38.16 \\
\hline 5. & Seed setting (\%) & 94.24 & 8.13 & 51.19 & 20.16 & 39.42 \\
\hline 6. & Sprouting (\%) & 96.67 & 36.67 & 66.67 & 14.85 & 22.27 \\
\hline 7. & Rooting (\%) & 98.33 & 13.89 & 56.11 & 17.33 & 30.89 \\
\hline 8. & Achene number/fruit & 118.10 & 12.53 & 65.32 & 17.09 & 26.16 \\
\hline 9. & Seed number/fruit & 47.86 & 2.99 & 25.43 & 10.12 & 39.79 \\
\hline 10. & 100 seed weight $(\mathrm{g})$ & 0.166 & 0.019 & 0.0925 & 0.03 & 32.43 \\
\hline
\end{tabular}

Among the studied genotypes, the seed number per fruit (CV-39.79\%) was presented the highest quantitative variation which was followed by seed setting percentage (CV-39.42\%), single fruit weight (CV-39.23\%) and fruits weight per plant $(38.16 \%)$. However, the fruit length ranged from $0.73 \mathrm{~cm}$ to $1.9 \mathrm{~cm}$ with an average $1.21 \mathrm{~cm}$. The maximum longest fruit was found in BSRM-56 $(5.58 \mathrm{~cm})$, BSRM-1 $(3.7 \mathrm{~cm})$, BSRM-34 $(3.4 \mathrm{~cm})$, BSRM-22 $(3.08 \mathrm{~cm})$ and BSRM-21 respectively. The ranged of fruit width from $0.52 \mathrm{~cm}$ to $1.9 \mathrm{~cm}$ with an average $1.21 \mathrm{~cm}$ and achene number per fruit was 12.53 to 118.10 with an average 65.32 . However, the maximum fruit width was observed in BSRM$56(1.9 \mathrm{~cm})$ followed by BSRM-1 $(1.72 \mathrm{~cm})$ and BSRM-34 $(1.7 \mathrm{~cm})$ respectively. Single fruit weight was varied 0.07 to $4.11 \mathrm{~g}$ with an average $2.09 \mathrm{~g}$. The maximum single fruit weight was in BSRM-56 (4.11 g) followed by BSRM-1 (3.43 g) and BSRM-34 (2.49 g) respectively. The ranged of fruit weight per plant was 101.47 to $2250.43 \mathrm{~g}$ with an average $1175.95 \mathrm{~g}$. Furthermore, the maximum fruit weight per plant was found in germplasm BSRM-56 (2250.43 g) which was followed by BSRM-1 (1750.63 g) and BSRM-34 $(1700.50 \mathrm{~g})$, respectively, whereas minimum fruit weight per plant was in BSRM-48 (151.77 g). Similarly, a previous study was conducted by [8] on important fruit traits of 93 mulberry accessions and they found the wide range of variation among the fruit length, single fruit weight and fruit weight per plant. 
They obtained the maximum fruit length, single fruit weight as well as fruit weight per plant was $4.2 \mathrm{~cm}, 3.3 \mathrm{~g}$ and $7261 \mathrm{~g}$ respectively. Furthermore, a previous study conducted on mulberry fruits indicated fruit length between 17.39 to $27.01 \mathrm{~mm}$, fruit width 10.89 to $17.91 \mathrm{~mm}$ and single fruit weight per plant 1.38 to $3.77 \mathrm{~g}$ respectively among 13 mulberry genotypes sampled in the Mus province in the eastern Anatolia region of Turkey [26]. In mulberry breeding programs superior fruit weight is one of the most significant advantageous fruit characteristics [27] which was observed among the studied accessions. Rooting percentage ranged from 13.89 to $98.33 \%$ with an average $56.11 \%$. Seed setting percentage ranged from 8.13 to $94.24 \%$ with an average $51.19 \%$ and sprouting\% ranged from 36.67 to $96.67 \%$ with an average $66.6 \%$. Similarly, [26] observed the great variation of sprouting percentage among the 10 mulberry genotypes where the sprouting percentage was above $95 \%$ in TRs, TR12 and S1708 mulberry varieties respectively. The maximum sprouting percentage was $98 \%$ in M5 variety followed by the TRs (97\%) and S1708 (96\%) varieties respectively. The maximum rooting percentage was in BSRM-10 (98.33\%) followed by BSRM-8 (94.21\%), BSRM28 (93.98\%), BSRM-15 (93.29\%), BSRM-26 (92.26\%) and BSRM-5 (90.48\%) respectively. Achene number per fruit ranged from 12.53 to 118.10 with an average 65.32 and the maximum achene number per fruit was 118.10 in BSRM-56 followed by BSRM-1 (91.93) and BSRM-34 (60.23) respectively. The ranged of seed number per fruit was 2.99 to 47.86 with an average 25.43 . The maximum seed number per plant was 47.86 in BSRM-56 followed by BSRM-1 (47.83) and BSRM-34 (46.97) respectively. Similarly, in a previous study was observed the great tend to the number of seed contained among the genotypes [28]. They showed that genotypes belonging to $M$. bombysis generally tended to have fewer seeds ( $<5$ seeds), while $M$. alba genotypes contained 25 to 30 seeds per fruits and $M$. latifolia genotypes contained 15 to 35 seeds per fruits. Of these, several genotypes had $>50$ seeds per fruit - for example, Okarag-uwa had 80 seeds and Kanadasansou B had 53 seeds and they also found that genotypes, Oushuguwa and Memurasaki had no seeds which was correlated with our experimental findings. The weight of 100 seed was varied 0.019 to $0.166 \mathrm{~g}$ with an average $0.03 \mathrm{~g}$. The maximum 100 seed weight was $0.166 \mathrm{~g}$ in BSRM-56 germplasm followed by BSRM-1 $(0.164 \mathrm{~g})$ and BSRM-34 $(0.157 \mathrm{~g})$ respectively (Table $\mathrm{V})$. They also observed wide range of variation among the seed weight of various genotypes [29]. The ranged of seed weight was $0.6 \mathrm{mg}$ (Isebudou genotype) to $68.2 \mathrm{mg}$ (Okaraguwa genotype) which was lined with our findings. Likewise, in a previous study [15] observed the wide range variation for rooting\%, seed setting\%, achene number per fruit and 100 seed weight of mulberry genotypes. The individual data of each germplasm is shown (Table VI).

TABLE VI: QUANTITATIVE VARIATION OF FRUITS FOR DIFFERENT CHARACTERS OF MULBERRY GERMPLASM

\begin{tabular}{|c|c|c|c|c|c|c|c|c|c|c|c|}
\hline SI. No. & $\begin{array}{c}\text { Name of } \\
\text { germplasm }\end{array}$ & $\begin{array}{c}\text { Fruit length } \\
(\mathrm{cm})\end{array}$ & $\begin{array}{c}\text { Fruit width } \\
(\mathrm{cm})\end{array}$ & $\begin{array}{c}\text { Single Fruit } \\
\text { weight }(\mathrm{g})\end{array}$ & $\begin{array}{c}\text { Fruit } \\
\text { weight/plant (g) }\end{array}$ & $\begin{array}{c}\text { Sprouting } \\
(\%)\end{array}$ & Rooting (\%) & $\begin{array}{c}\text { Seed setting } \\
(\%)\end{array}$ & $\begin{array}{c}\text { Achene } \\
\text { number/fruit }\end{array}$ & $\begin{array}{c}\text { Seed } \\
\text { number/fruit }\end{array}$ & $\begin{array}{c}100 \text { seed } \\
\text { weight }(\mathrm{g})\end{array}$ \\
\hline 1. & BSRM-1 & 3.7 & 1.72 & 3.43 & 1750.63 & 75 & 57.45 & 85.66 & 91.93 & 47.83 & 0.164 \\
\hline 2. & BSRM-2 & 1.33 & 0.87 & 0.42 & 1000.77 & 71.67 & 69.7 & 81.63 & 28.60 & 23.22 & 0.131 \\
\hline 3. & BSRM-3 & 1.25 & 0.88 & 0.39 & 109.63 & 95 & 79.04 & 89.40 & 21.21 & 18.84 & 0.127 \\
\hline 4. & BSRM-4 & 1.64 & 1.13 & 0.71 & 350.17 & 48.33 & 43.65 & 86.54 & 31.54 & 27.30 & 0.123 \\
\hline 5. & BSRM-5 & 1.34 & 0.82 & 0.47 & 300.35 & 76.67 & 90.48 & 67.63 & 31.64 & 21.41 & 0.134 \\
\hline 6. & BSRM-6 & 1.82 & 1.06 & 0.88 & 375.51 & 64.5 & 88.89 & 89.05 & 35.99 & 32.16 & 0.114 \\
\hline 7. & BSRM-7 & 1.34 & 1.04 & 0.62 & 611.77 & 68.33 & 71.43 & 74.29 & 25.07 & 20.20 & 0.126 \\
\hline 8. & BSRM-8 & 0.73 & 0.52 & 0.07 & 167.77 & 85 & 94.21 & 22.82 & 13.01 & 2.99 & 0.139 \\
\hline 9. & BSRM-10 & 1.06 & 0.68 & 0.24 & 275.67 & 93.33 & 98.33 & 28.86 & 12.53 & 3.43 & 0.071 \\
\hline 10. & BSRM-11 & 1.82 & 0.93 & 0.77 & 101.47 & 95 & 79.18 & 71.40 & 29.22 & 20.85 & 0.126 \\
\hline 11. & BSRM-12 & 1.41 & 0.67 & 0.53 & 151.55 & 75 & 75.4 & 70.50 & 28.64 & 20.16 & 0.149 \\
\hline 12. & BSRM-13 & 1.8 & 0.99 & 0.72 & 350.87 & 75 & 75.74 & 82.10 & 36.50 & 30.27 & 0.108 \\
\hline 13. & BSRM-14 & 1.6 & 0.9 & 0.69 & 401.77 & 90 & 88.89 & 87.15 & 35.55 & 30.96 & 0.140 \\
\hline 14. & BSRM-15 & 2 & 1.11 & 1.29 & 550.89 & 85 & 93.29 & 81.56 & 38.41 & 31.34 & 0.171 \\
\hline 15. & BSRM-16 & 2.3 & 1.07 & 1.54 & 275.61 & 43 & 59.58 & 94.24 & 50.78 & 25.57 & 0.141 \\
\hline 16. & BSRM-18 & 1.84 & 1.05 & 0.73 & 450.43 & 58.33 & 71.95 & 57.91 & 34.07 & 19.87 & 0.110 \\
\hline 17. & BSRM-19 & 1.4 & 0.86 & 0.56 & 600.44 & 81.67 & 89.31 & 83.56 & 27.77 & 23.23 & 0.131 \\
\hline 18. & BSRM-20 & 1.8 & 0.97 & 0.96 & 1001.86 & 61.67 & 67.5 & 91.29 & 35.36 & 32.35 & 0.136 \\
\hline 19. & BSRM-21 & 2.83 & 1.4 & 2.45 & 1150.33 & 56.67 & 54.42 & 54.91 & 47.77 & 26.13 & 0.150 \\
\hline 20. & BSRM-22 & 3.08 & 1.28 & 1.97 & 701.13 & 36.67 & 13.89 & 16.65 & 40.97 & 10.05 & 0.134 \\
\hline 21. & BSRM-23 & 1.77 & 0.84 & 0.79 & 375.53 & 91.67 & 87.38 & 75.58 & 30.65 & 23.13 & 0.105 \\
\hline 22. & BSRM-25 & 1.71 & 0.87 & 0.98 & 331.66 & 73.33 & 81.01 & 78.07 & 27.69 & 21.70 & 0.125 \\
\hline 23. & BSRM-26 & 1.84 & 1.03 & 1.13 & 900.91 & 90 & 92.26 & 86.36 & 40.55 & 35.06 & 0.108 \\
\hline 24. & BSRM-27 & 1.77 & 0.79 & 0.88 & 376.55 & 90 & 79.2 & 64.09 & 38.48 & 24.73 & 0.150 \\
\hline 25. & BSRM-28 & 1.65 & 0.86 & 0.69 & 700.33 & 86.67 & 93.98 & 86.25 & 37.96 & 32.75 & 0.105 \\
\hline 26. & BSRM-29 & 2.8 & 1.8 & 2.49 & 650.23 & 55 & 33.06 & 8.13 & 46.69 & 9.60 & 0.019 \\
\hline 27. & BSRM-30 & 2.24 & 1.07 & 1.24 & 550.13 & 61.67 & 85.63 & 80.38 & 40.53 & 33.31 & 0.150 \\
\hline 28. & BSRM-33 & 1.7 & 0.87 & 0.72 & 300.41 & 81.67 & 82.59 & 89.12 & 29.00 & 25.83 & 0.136 \\
\hline 29. & BSRM-34 & 3.4 & 1.7 & 2.49 & 1700.55 & 75 & 87.67 & 80.48 & 60.23 & 46.97 & 0.157 \\
\hline 30. & BSRM-35 & 1.36 & 0.71 & 0.32 & 150.77 & 86.67 & 72.71 & 78.02 & 20.28 & 15.81 & 0.091 \\
\hline 31. & BSRM-36 & 1.93 & 0.92 & 0.91 & 475.23 & 56.67 & 65.28 & 58.14 & 44.95 & 26.13 & 0.110 \\
\hline 32. & BSRM-37 & 1.36 & 0.93 & 0.35 & 450.31 & 79.67 & 55.79 & 73.41 & 24.38 & 18.00 & 0.142 \\
\hline 33. & BSRM-38 & 1.79 & 0.99 & 0.83 & 350.47 & 96.67 & 57.96 & 70.92 & 31.23 & 22.20 & 0.147 \\
\hline 34. & BSRM-40 & 1.93 & 1.14 & 1.05 & 750.27 & 70 & 63.89 & 85.98 & 37.75 & 32.57 & 0.116 \\
\hline 35. & BSRM-42 & 2.13 & 1.14 & 1.12 & 800.53 & 50 & 64.37 & 93.22 & 47.59 & 44.34 & 0.147 \\
\hline
\end{tabular}


TABLE VI: QUANTITATIVE VARIATION OF FRUITS FOR DIFFERENT CHARACTERS OF MULBERRY GERMPLASM

\begin{tabular}{|c|c|c|c|c|c|c|c|c|c|c|c|}
\hline SI. No. & $\begin{array}{c}\text { Name of } \\
\text { germplasm }\end{array}$ & $\begin{array}{l}\text { Fruit length } \\
(\mathrm{cm})\end{array}$ & $\begin{array}{l}\text { Fruit width } \\
(\mathrm{cm})\end{array}$ & $\begin{array}{l}\text { Single Fruit } \\
\text { weight }(\mathrm{g})\end{array}$ & $\begin{array}{c}\text { Fruit } \\
\text { weight/plant (g) }\end{array}$ & $\begin{array}{c}\text { Sprouting } \\
(\%)\end{array}$ & Rooting (\%) & $\begin{array}{c}\text { Seed setting } \\
(\%)\end{array}$ & $\begin{array}{c}\text { Achene } \\
\text { number/fruit }\end{array}$ & $\begin{array}{c}\text { Seed } \\
\text { number/fruit }\end{array}$ & $\begin{array}{c}100 \text { seed } \\
\text { weight }(\mathrm{g})\end{array}$ \\
\hline 36. & BSRM-45 & 2.39 & 1.07 & 1.3 & 1200.67 & 90 & 89.25 & 90.12 & 34.76 & 31.52 & 0.128 \\
\hline 37. & BSRM-46 & 2.3 & 1.4 & 1.97 & 450.52 & 86.61 & 77.34 & 89.92 & 33.21 & 30.13 & 0.126 \\
\hline 38. & BSRM-47 & 2 & 0.8 & 0.357 & 155.57 & 84.67 & 81.3 & 87.78 & 32.11 & 29.79 & 0.125 \\
\hline 39. & BSRM-48 & 1.7 & 0.8 & 0.349 & 151.77 & 88.77 & 77.81 & 89.11 & 25.76 & 25.85 & 0.137 \\
\hline 40. & BSRM-49 & 1.9 & 1.5 & 1.77 & 503.33 & 89.97 & 81.3 & 57.91 & 44.92 & 25.93 & 0.111 \\
\hline 41. & BSRM-50 & 2.24 & 1.09 & 1.21 & 650.76 & 91.67 & 67.77 & 87.89 & 45.47 & 28.77 & 0.149 \\
\hline 42. & BSRM-51 & 1.5 & 0.8 & 0.57 & 0.9 & 89.97 & 63.67 & 86.67 & 24.77 & 24.33 & 0.135 \\
\hline 43. & BSRM-53 & 2 & 1.2 & 1.29 & 550.63 & 79.97 & 73.37 & 84.67 & 39.27 & 43.41 & 0.145 \\
\hline 44. & BSRM-54 & 2.1 & 1.67 & 1.53 & 273.65 & 42.11 & 59.37 & 93.78 & 49.63 & 33.00 & 0.143 \\
\hline 45. & BSRM-55 & 2.24 & 1.09 & 1.06 & 350.13 & 88.7 & 69.73 & 95.57 & 49.99 & 33.09 & 0.139 \\
\hline 46. & BSRM-56 & 5.58 & 1.9 & 4.11 & 2250.43 & 77.87 & 87.61 & 91.67 & 118.10 & 47.86 & 0.166 \\
\hline 47. & BSRM-57 & 2.7 & 1.8 & 2.39 & 201.29 & 75.63 & 59.8 & 89.97 & 45.79 & 24.37 & 0.148 \\
\hline 48. & BSRM-59 & 1.9 & 1.5 & 1.463 & 800.33 & 86.67 & 79.79 & 88.99 & 44.93 & 33.57 & 0.146 \\
\hline $49 .$. & BSRM-60 & 2.21 & 1.09 & 1.31 & 751.19 & 88.71 & 83.31 & 93.79 & 49.33 & 46.77 & 0.145 \\
\hline 50. & BSRM-61 & 1.9 & 1.3 & 1.316 & 902.41 & 91.1 & 83.67 & 88.96 & 42.32 & 33.67 & 0.147 \\
\hline
\end{tabular}

However, several findings of our research are similar and some of the findings were disagreement with the above mentioned findings which might be due to the owed variability of used mulberry species or genotypes as well as edaphic and environmental factors that prevailing at the experimental site. Besides, it could be due to the comparatively larger fruit length and width the single fruit weight, fruit weight per plant, achene number per fruit, seed number per fruit and 100 seed weight were varied among the genotypes.

The identified leading traits were accounted by employed of PCA on the basis of higher fractions of overall variability to reduce the complexity among the experimental space and clearly visualize groupings, which was not possibly emerge from the raw data, [30]. However, the differentiations between genotypes were estimated on the PCA based correlation matrix and ten principal components, which explained $100 \%$ of the total difference (Table VII).

The result indicates that these charters had the maximum dissimilarity between the genotypes and also had the greatest impact on division of them [31]. 99.36\% was accounted for first function which is largely inclined by seed setting and sprouting percentage. The second function was $0.306 \%$ of total variation which was mainly explained by acheine number per fruit, single fruit weight, and fruit width and fruit length respectively. In the same way, the third function was accounted for $0.185 \%$ of total variation that was commonly inclined by the traits of fruit production per plant, seed setting and sprouting percentage respectively. The fourth, fifth and six functions were accounted for $0.092 \%, 0.046 \%$ and $0.008 \%$ respectively. In case of fourth function 100 seed weight and rooting $\%$, for fifth function fruit length, single fruit weight, seed setting\%, fruit breath, fruit production per plant and rooting $\%$ as well as for six function all the traits except sprouting\%, rooting\% and achene number per fruit were mostly influenced. Furthermore, the seven, eight, nine and ten functions were accounted more than 100 percentage of total variation and the cumulative $\%$ of variation was 100 (Table VII).

TABLE VII: EIGENVALUES AND PROPORTION OF TOTAL VARIABILITY AND EIGENVECTORS OF TEN PRINCIPAL COMPONENTS (PCS) FOR STUDIED MULBERRY GENOTYPES

\begin{tabular}{|c|c|c|c|c|c|c|c|c|c|c|}
\hline \multirow{2}{*}{ Variables } & \multicolumn{10}{|c|}{ Components } \\
\hline & 1 & 2 & 3 & 4 & 5 & 6 & 7 & 8 & 9 & 10 \\
\hline Fruit length $(\mathrm{cm})$ & $-3.21 \mathrm{E}-04$ & $1.63 \mathrm{E}-02$ & $-1.45 \mathrm{E}-02$ & $-2.62 \mathrm{E}-02$ & $9.79 \mathrm{E}-03$ & $4.82 \mathrm{E}-03$ & $4.92 \mathrm{E}-01$ & $8.46 \mathrm{E}-01$ & $-1.99 \mathrm{E}-01$ & $-3.15 \mathrm{E}-02$ \\
\hline Fruit width $(\mathrm{cm})$ & $-1.91 \mathrm{E}-04$ & $2.65 \mathrm{E}-05$ & $-1.03 \mathrm{E}-02$ & $-3.68 \mathrm{E}-03$ & $2.94 \mathrm{E}-03$ & $2.06 \mathrm{E}-02$ & $2.88 \mathrm{E}-01$ & $-3.76 \mathrm{E}-01$ & $-8.80 \mathrm{E}-01$ & $-2.79 \mathrm{E}-02$ \\
\hline Fruit production/plant $(\mathrm{g})$ & $-1.00 \mathrm{E}+00$ & $-3.15 \mathrm{E}-03$ & $8.75 \mathrm{E}-03$ & $1.45 \mathrm{E}-03$ & $2.62 \mathrm{E}-03$ & $9.40 \mathrm{E}-04$ & $-3.74 \mathrm{E}-04$ & $5.64 \mathrm{E}-05$ & $-6.79 \mathrm{E}-06$ & 2.61E-06 \\
\hline Seed setting $(\%)$ & $5.45 \mathrm{E}-03$ & $-4.14 \mathrm{E}-01$ & $3.42 \mathrm{E}-01$ & $-5.04 \mathrm{E}-01$ & $6.54 \mathrm{E}-01$ & $1.69 \mathrm{E}-01$ & $-2.08 \mathrm{E}-02$ & $1.07 \mathrm{E}-03$ & $-3.00 \mathrm{E}-03$ & 5.97E-05 \\
\hline Sprouting (\%) & $1.66 \mathrm{E}-03$ & $-5.13 \mathrm{E}-01$ & $2.92 \mathrm{E}-01$ & $-3.51 \mathrm{E}-01$ & $-7.14 \mathrm{E}-01$ & $-1.33 \mathrm{E}-01$ & $1.95 \mathrm{E}-02$ & $1.32 \mathrm{E}-03$ & $-1.64 \mathrm{E}-03$ & $-4.65 \mathrm{E}-04$ \\
\hline Rooting (\%) & $-3.66 \mathrm{E}-03$ & $-6.05 \mathrm{E}-01$ & $-6.67 \mathrm{E}-01$ & $1.34 \mathrm{E}-01$ & $1.67 \mathrm{E}-01$ & $-3.78 \mathrm{E}-01$ & $1.46 \mathrm{E}-02$ & $-2.70 \mathrm{E}-03$ & $4.80 \mathrm{E}-03$ & 4.23E-04 \\
\hline Seed number/fruit & $-3.20 \mathrm{E}-03$ & $-1.36 \mathrm{E}-01$ & $-4.35 \mathrm{E}-01$ & $-1.26 \mathrm{E}-01$ & $-1.80 \mathrm{E}-01$ & $8.60 \mathrm{E}-01$ & $-6.15 \mathrm{E}-02$ & $2.31 \mathrm{E}-02$ & $-4.86 \mathrm{E}-03$ & $2.53 \mathrm{E}-04$ \\
\hline 100 seed weight $(\mathrm{g})$ & $-5.27 \mathrm{E}-06$ & $-4.24 \mathrm{E}-04$ & $-3.89 \mathrm{E}-04$ & $3.54 \mathrm{E}-04$ & $2.96 \mathrm{E}-04$ & $1.41 \mathrm{E}-03$ & $3.45 \mathrm{E}-03$ & $-2.86 \mathrm{E}-02$ & 4.50E-02 & $-9.99 \mathrm{E}-01$ \\
\hline Standard deviation & 449.93 & 24.96 & 19.40 & 13.66 & 9.66 & 3.95 & 0.71 & 0.29 & 0.11 & 0.02 \\
\hline Percentage of variation & 99.36 & 0.306 & 0.185 & 0.092 & 0.046 & 0.008 & 0 & 0 & 0 & 0 \\
\hline Cumulative $\%$ & 99.36 & 99.67 & 99.855 & 99.946 & 99.992 & 100 & 100 & 100 & 100 & 100 \\
\hline
\end{tabular}

In our study the significantly positive correlations were found among the studied characteristics of mulberry genotypes for simple correlation analysis (Table VIII).

From the correlation analysis, it is seen that the selfcontribution of fruit length towards the achene number per fruit was highly positive which signifies that the attribute is remarkable responsive for direct selection towards the improvement of fruit in mulberry. Fruit width (FW) was observed to have a highly positive relationship with SFW and SNF respectively but strongly and negatively correlated with
SS and SP. Seed setting\% was highly positively correlated with SP and RP respectively. RP was found highly and positively related with SNF and SW but strongly and negatively related with FL and ANF. Highly positive association of SP and SS that indicates percentage of seed setting greatly influenced the sprouting percentage of mulberry. ANF and SNF exhibited highly positive association between fruit length and rooting\% respectively. 100 seed weight was found positively correlated almost all the traits except fruit length and achene number per fruit. 
However, in this study the fruit weight per plant was positively correlated with fruit length, fruit width, single fruit weight, achene number per fruit and seed number per fruit. These results were lined with previous findings of [32] in chestnut and $[33 ; 10]$ in mulberry who, reported that length and width of the fruit were highly associated with fruit weight as well as fruit size and fruit weight were also significantly linked with each other.

\begin{tabular}{|c|c|c|c|c|c|c|c|c|c|c|}
\hline Characters & $\begin{array}{l}\text { Fruit length } \\
(\mathrm{cm})\end{array}$ & $\begin{array}{l}\text { Fruit width } \\
(\mathrm{cm})\end{array}$ & $\begin{array}{l}\text { Single fruit } \\
\text { weight (g) }\end{array}$ & $\begin{array}{c}\text { Fruit weight/ } \\
\text { plant }(\mathrm{g})\end{array}$ & $\begin{array}{c}\text { Seed setting } \\
(\%)\end{array}$ & $\begin{array}{c}\text { Sprouting } \\
(\%)\end{array}$ & Rooting (\%) & $\begin{array}{c}\text { Achene } \\
\text { number/fruit }\end{array}$ & $\begin{array}{c}\text { Seed } \\
\text { number/fruit }\end{array}$ & $\begin{array}{c}100 \text { seed } \\
\text { weight }(\mathrm{g})\end{array}$ \\
\hline FL & 1 & & & & & & & & & \\
\hline FW & 0.516 & 1 & & & & & & & & \\
\hline SFW & 0.716 & 0.882 & 1 & & & & & & & \\
\hline FWP & 0.188 & 0.248 & 0.246 & 1 & & & & & & \\
\hline SS & -0.280 & -0.178 & -0.089 & -0.157 & 1 & & & & & \\
\hline SP & -0.467 & -0.211 & -0.201 & -0.045 & 0.629 & 1 & & & & \\
\hline $\mathrm{RP}$ & -0.182 & 0.363 & 0.163 & 0.081 & 0.199 & 0.303 & 1 & & & \\
\hline ANF & 0.809 & 0.378 & 0.482 & 0.167 & -0.373 & -0.459 & -0.210 & 1 & & \\
\hline SNF & 0.219 & 0.600 & 0.483 & 0.142 & -0.135 & 0.079 & 0.745 & 0.286 & 1 & \\
\hline SW & -0.234 & 0.337 & 0.243 & 0.094 & 0.106 & 0.110 & 0.523 & -0.240 & 0.424 & 1 \\
\hline
\end{tabular}

Here, FL = Fruit length, FW = Fruit Width, SFW = Single Fruit Weight, FWP = Fruit Weight per Plant, SS = Seed Setting Percentage, SP = Sprouting Percentage, $\mathrm{RP}=$ Rooting Percentage, $\mathrm{ANF}=$ Achene Number per Fruit, $\mathrm{SNF}=$ Seed Number per Fruit and $\mathrm{SW}=100 \mathrm{Seed} \mathrm{Weight}$.

\section{CONCLUSION}

In our study, some morphological fruit characters of 50 mulberry genotypes grown in Bangladesh have been analyzed. To the best of our awareness, it is very limited research on this subject. However, the results indicate substantial variability among the studied germplasms. As a conclusion it can be said that the most divergent genotypes obtained in this study can be used in future mulberry crop improvement program.

\section{ACKNOWLEDGMENT}

This work was financially supported by using the research fund of World Bank, IFAD, and GoB through Ministry of Agriculture. We would like to acknowledge to the World Bank for arranging the research fund and supervising the PBRGs by BARC. It was worthwhile to mention the cooperation and quick responses of PIU-BARC, NATP-2 in respect of field implementation of the sub-project in multiple sites. The authors are thankful to the technical staff of Bangladesh Sericulture Research and Training Institute (BSRTI), Rajshahi for their assist towards experimentation. Finally, we are indebted to the Director of Bangladesh Sericulture Research and Training Institute (BSRTI), Rajshahi, for granting us permission to use the mulberry germplasm bank, valuable assistance and providing laboratory facilities for analytical analysis for this study.

\section{REFERENCES}

[1] A. S. Hosseini, M. Akramian, A. Khadiviand H. S. Arjmand, "Phenotypic and Chemical Variation of Black Mulberry (Morus nigra) Genotypes",Industrial Crops and Products, vol. 117, pp. 260-271, 2018.

[2] Tikader and K. Vijayan, "Assessment of Biodiversity and Strategies for Conservation of Genetic Resources in Mulberry (Morus spp.)", Bioremediation, Biodiversity and Bioavailability, vol. 4, pp. 15-27, 2010.

[3] N. Gungor and M. Sengul, "Antioxidant Activity, Total Phenolic Content and Selected Physicochemical Properties of White Mulberry (Morus alba L.) Fruits", International Journal of Food Properties, vol. 11, pp. 44-52, 2008.

[4] S. Ercisli and E. Orhan, "Chemical Composition of White (Morus alba) Red (Morus rubra) and Black (Morus nigra) Mulberry Fruits", Food
Chemistry, vol. 103, pp. 1380-1384, 2007, doi:10.1016/j.foodchem.2006.10.054.

[5] S. Kafkas, M. Ozgen, Y. Dogan, B. Ozcan, S. Ercisli and S. Serce,"Molecular Characterization of Mulberry Accessions in Turkey by AFLP Markers",Journal of the American Society for Horticultural Science, vol. 133, pp. 593-597, 2008.

[6] K. Vijayan, S. P. Chakraborti, S. Ercisli and P. D. Ghosh, "NaCI Induced Morpho-Biochemical and Anatomical Changes in Mulberry (Morus spp.)",Plant Growth Regulation, vol. 56, no. 1, pp. 61-69, 2008.

[7] Q. Yuan and L. Zhao, "The Mulberry (Morus alba L.) Fruit: A review of Characteristic Components and Health Benefits",Journal of Agricultural and Food Chemistry, vol. 65, pp. 10383-10394, 2017.

[8] H. Zhang, Z. F. Ma, X. Luo and X. Li, "Effects of Mulberry Fruit (Morus alba L.) Consumption on Health Outcomes: a Mini-review", Antioxidants, Basel. Switzerland, vol. 7, no. 5, pp. 69, 2018.

[9] S. Skrovankova, D. Sumczynski,J. Mlcek, T. Jurikovaand J. Sochor, "Bioactive Compounds and Antioxidant Activity in Different Types of Berries",International Journal of Molecular Science, vol. 16, no. 10, pp. 24673-24706, 2015.

[10] H. Krishna and A. Parashar, "Phytochemical Constituents and Antioxidant Activities of Some Indian Jujube (Ziziphus mauritianaLamk.) Cultivars",Journal of Food Biochemistry, vol. 37, no. 5, pp. 571-577, 2013.

[11] Y. Jiang and W. J. Nie, "Chemical Properties in Fruits of Mulberry Species from the Xinjiang Province of China". Food Chemistry, vol. 174, pp. 460-466, 2015.

[12] M. Gundogdu, I. Canan, M. K. Gecer, T. Kan and S. Ercisli, "Phenolic Compounds, Bioactive Content and Antioxidant Capacity of the Fruits of Mulberry (Morus spp.) Germplasm in Turkey". Folia Horticulturae, vol. 29, no. 2, pp. 251-262, 2017.

[13] T. Mahmood, F. Anwar, N. Afzal, R. Kausar, S. Ilyas and M. Shoaib, "Influence of Ripening Stages and Drying Methods on Polyphenolic Content and Antioxidant Activities of Mulberry Fruits", Journal of Food Measurement and Characterization, vol. 11, no. 4, pp. 21712179, 2017.

[14] M. M. Natic, D. C. Dabic, A. Papetti, M. M. F. Akšic, V. Ognjanov, M. Ljubojevicand Z. L. Tešic, "Analysis and Characterisation of Phytochemicals in Mulberry (Morus alba L.) Fruits Grown in Vojvodina". North Serbia. Food Chemistry, vol. 171, pp. 128-136, 2015.

[15] M. S. Rahman, "Studies on genetic variability in mulberry (Morusspp)",Ph.D. Thesis, Rajshahi University, 2001.

[16] M. S. Lin, "Genetic Base of Japonica Rice Varieties Released in Taiwan", Euphytica, vol. 56, pp. 43-46, 1991.

[17] M. Elias, D. Mckey, O. Panaud, M. C. Anstettand T. Robert, "Traditional Management of cassava Morphological and Genetic Diversity by the Makushi Amerindians (Guyana, South America): Perspectives for On-farm Conservation of Crop Genetic Resources",Euphytica, vol. 120, pp. 57-143, 2001.

[18] A. M. Zacarias, A. M. Botha, M. T. Labuschagne and I. R. M. Benesi, "Characterization and Genetic Distance Analysis of Cassava (Manithol esculenta Crantz) Germplasm from Mozambique using RAPD Fingerprinting', Euphytica, vol. 138, pp. 49-53, 2004.

[19] E. Ertan, "Variability in leaf and fruit morphology and in fruit composition of chestnuts (Castanea sativa Mill.) in the Nazilli region 
of Turkey", Genetic Resources and Crop Evolution, vol. 54, no. 4, pp. 691-699.2007.

[20] Annual Research Report of BSRTI, Bangladesh Sericulture Research and Training Institute, Rajshahivol. 25, no. 9, pp. 25-29, 2002.

[21] C. Hacketr, "A rapidly searchable Compendium of information on cultivated fruit, vegetable, spice and nutspecices",ChronicaHorticulturae, vol. 19, no. 2, pp. 31, 1979.

[22] CSRTI, "Mulberry Descriptor. Central Sericultural Research and Training Institute Central Silk Board", Srirampuram, India, 1986.

[23] H. Krishna, D. Singh, R. S. Singh, L. Kumar, B. D. Sharma, Saroj, Morphological and antioxidant characteristics of mulberry (Morus spp.) genotypes, Journal of the Saudi Society of Agricultural Sciences, vol. 19, no. 2, pp. 136-145, 2018.

[24] K. Vijayan, A. Tikader, Z. Weiguo, C. V. Nair, S. Ercisli and C. Tsou, "Wild Crop Relatives: Genomic and Breeding Resources, Tropical and Subtropical Fruits", Springer-Verlag Berlin Heidelberg, 2011, DOI. 10.1007/978-3-642-20447-0_5.

[25] M. Boubaya, Ben-Salah, N. Marzouguiand A. Ferchichi, "Pomological characterization of the mulberry tree (Morus spp.) in the South of Tunisia”,Journal of Arid Land Studies, vol. 19, no. 1, pp. 157-159, 2009.

[26] Balik, M.K. Gecer and R. Aslantas, "Diversity of Biochemical Content in Fruits of Some Indigenous Mulberry Genotypes",Turkish Journal of Agriculture and Forestry, vol. 43, pp. 28-35, 2019.

[27] F. Aljaneand N. Sdiri, "Morphological Phytochemical and Antioxidant Characteristics of White (Morus alba L.), Red (Morus rubra L.) and Black (Morus nigra L.) Mulberry Fruits Grown in Arid Regions of Tunisia",New Journal of Science, vol. 35, no. 1, pp. 1940-1947. 2016.

[28] V. N. Y. Murthy, H. L. Ramesh, Munirajappa and B. R. D. Yadav, "Screening of Selected Mulberry (Morus) Germplasm Varieties through Propagation Parameters", Journal of Natural Sciences Research, vol. 2, no. 5, pp. 96-106,2012.

[29] H. Machii, A. Koyama and H. Yamanouchi, "Fruit traits of genetic mulberry resources", Journal of Sericultural Science of Japan, vol. 68, no. 2, pp. $145-155,1999$.

[30] A. D. Matteo, R. Russo, G. Graziani, A. Ritieni and C. D. Vaio, "Characterization of Autochthonous Sweet Cherry Cultivars (Prunus avium L.) of Southern Italy for Fruit Quality, Bioactive Compounds and Antioxidant Activity",Journal of the Science of Food and Agriculture, vol. 97, pp. 2782-2794, 2017.

[31] F. Iezzoni, M. P. Pritts and A. Kumar, "Applications of Principal Component Analysis to Horticultural Research", HortScience, vol. 26, pp. 334-338,1991.

[32] T. Marinoni, A. Akkak, C. Beltramo, P. Guaraldo, P. Boccacci,G. Bounous, A. M. Ferrara, A. Ebone, E. Viotto and R. Botta, "Genetic and Morphological Characterization of Chestnut (Castanea sativa Mill.) Germplasm in Piedmont (north-western Italy)",Tree Genetics and Genomes, vol. 9, pp. 1017-1030,2013.

[33] N. W. Peris, K. M. Gacheri, M. M. Theophillusand N. Lucas, "Morphological Characterization of Mulberry (Morusspp) Accessions Grown in Kenya",Sustainable Agriculture Research, vol. 3, no. 1, pp. 10, 2014.

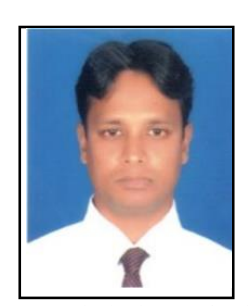

\section{Faruque Ahmed}

Birth place: Rajshahi, Date of birth: 31.12.1983, Educational background: Master of Science in Agronomy and Phd Fellow (Current), Field: Agronomy, Institution: Rajshahi University, City: Rajshahi, State or Country: Bangladesh, Year of Degree: 2009, Major field of study: agronomy. His work experience: 10 years, Job title: Senior Scientific Officer, Current job location: Bangladesh Sericulture Research and Training Institute (BSRTI), Rajshahi, Bangladesh. He has been published 13 research publication in different peer review international journal. His current and previous research interest is mulberry agronomy.

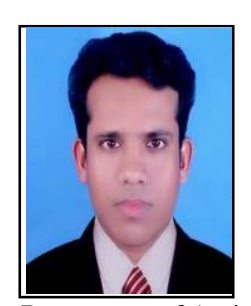

\section{Anwar Hossain}

Birth place: Netrakona, Date of birth: 15.07.1983, Educational background: Master of Science in Agricultural Extension, Field: Agricultural Extension,Institution: Rajshahi University, City: Rajshahi, State or Country: Bangladesh, Year of Degree: 2009, Major field of study: Extension. His work experience: 10 years, Job title:Upazila Agriculture Officer, Current job location: Department of Agricultural Extension (DAE), Gagargaon, Mymensingh.

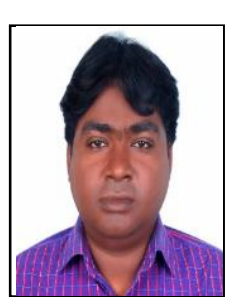

\section{Nasir Uddin Ahmed}

Birth place: Rajshahi, Date of birth: 01.01.1983, Educational background: Master of Science in Agricultural Extension, Field: Agricultural Extension, Institution: Rajshahi University, City: Rajshahi, State or Country: Bangladesh, Year of Degree: 2009, Major field of study: Extension.

His work experience: 10 years, Job title: Assistant Coordinator, Wave Foundation, Bangladesh.

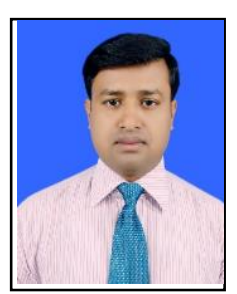

\section{Md. Jahangir Alam}

Birth place: Rajshahi, Date of birth: 03.12.1978, Educational background: Master of Science in Agronomy and Phd Fellow (Current), Field: Agronomy, Institution: Bangladesh Agricultural University (BAU), City: Mymensingh, State or Country: Bangladesh, Year of Degree: 2006, Major field of study: agronomy.

His work experience: 15 years, Job title: Senior scientific officer, Current job location: Cotton Development Board, Rajsahi, Bangladesh, He has been published 03 research publication in different peer review international journal. His current and previous research interest is agronomical management of cotton.

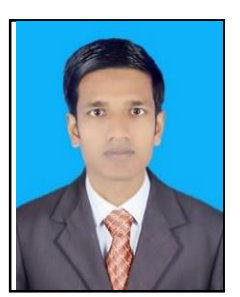

\section{Md. Shoriful Islam}

Birth place: Rajshahi, Date of birth: 15.01.1991, Educational background: Master of Science in Agronomy, Field: Agronomy, Institution: Rajshahi University, City: Rajshahi, State or Country: Bangladesh, Year of Degree: 2017, Major field of study: agronomy.

His work experience: 03 years, Job title: Research Assistant, Current job location: Christian Commission for Development in Bangladesh, His current and previous research interest is crop agronomy. 